\title{
МОНГОЛЫН ЗАГАСНЫ АЙМГИЙН ЗАРИМ ТӨРӨЛ ЗУЙЛИЙГ МОЛЕКУЛ-ФИЛОГЕНЕТИКИЙН АРГААР СУДАЛСАН ДҮНГЭЭС
}

\author{
А.Дулмаа \\ ШУА-ийн Загас үржүүлгийн эрдэм шинжилгээний төв \\ Цахим шуудан: adulmaа@yahoo.com
}

Төв Азийн бүсийн геотопологийн онцгой байрлалын улмаас энэхүҮ эх газрын гүн дэхь нутгийн усны амьдрал дэлхийн хийгээд бүсийн газарзүйн гео - цаг уурын хэлбэлзлээс ихэд хамааралтай байдаг. Монгол орны загасны аймгийн орчин цагийн төрх плиоцены ба плейстоцены үеийн зааг үед болсон дэлхийн хүйтрэлтэй шууд холбоотой нөхцөлдөн буй болжээ (Маринов, 1954). Төв Азийн газар нутаг дээр тектоникийн болон галт уулын идэвхжлийн нөхцлөөс үүдсэн хүйтрэл нь Монголын бүх үндсэн ай сав газруудын анхны гуравдагч галавын, дулааныг эрхэмлэгч Хятад болон Евросибирийн загасны аймгийн ихэнх зүйлүүдийг мөхөхөд хүргэжээ (Сычевская, 1991). Үүссэн усан сангуудын тусгаарлагдмал байдал, сүүлчийн гидрохимийн нөхцөлд хадгалагдаж үлдсэн цөөн тооны зүйлүүд нь бүс нутгийн унаган амьтад болж өөрчлөгдөн экологи, хорологийн чиглэлээр хувьсан хөгжжээ. Ялангуяа энэ үйл явц Их нууруудын хотгор, Говийн нууруудын хөндий, Алтайн Их уулсын болон Өрнөд Хангайн усан сангуудад тодоор илэрч байна.

Улмаар, нөхцөл байдал төлөвшин тогтворжих үед Сэлэнгэ мөрний саваар ихэвчлэн тархан нутагших болсон Евросибири ба Амарын мөрний төрөл зүйлс нь халуун, хүйтний /температурын/ болон усны горимын хэлбэлзэл, өндөр эрдэсжилт, тэжээлийн нөөцийн хомсдол зэрэг орчны хатуу ширүүн нөхцөл рүү шилжин оржээ.
Монгол орны усан сангуудын унаган болон нилээд түгээмэл загасны гол төлөөлөгч болох зүйлүүдэд популяцийн морфологи, популяцийн генетик судалгааг хийлээ. Унаган багийн гол төлөөлөгчөөр алтайн осман (Oreoleuciscus sp.), жунгарийн (зүҮн гарын) сугас (Leuciscus dzungaricus) загасыг сонгов. Түгээмэл зүйлүүдийн популяцийн байдлыг улаан нүдэн (Rutilus rutilus) болон нуурын варлан - Phoxinus perenurus, ердийн - Ph.phoxinus, лаговскийн - Ph.lagowski гэдэг 3 зүйлийг харьцуулсан жишээгээр үнэлгээ хийв. Өмнө нь Төв Азийн гадагш урсгалгүй ай савын усан сангуудад алтайн осман (Oreoleuciscus sp.) тусгаарлагдсан нь дасан зохицох явц хөгжиж, зүйлийн дотор морфо-экологийн янз бүрийн хэлбэрүүд бүрэлдэн буй болоход хүргэжээ гэж үзэж байсан юм (Дгебуадзе, Дулмаа 1992; Дгебуадзе,1982; Баасанжав бусад 1983, 1985).

Сэлэнгийн сав газраас шинээр олдсон алтайн османы (Oreoleuciscus humilis) популяцийн морфологи судалгаагаap эдгээр популяциудад дээр дурдсанчлан дасан зохицсон байдал гараагүй нь харагдлаа. Үүний сацуу генетик төрөлжилт нь Сэлэнгэ, Их нууруудын хотгор, Говийн нууруудын хөндийн ай сав газрын популяцийн бүлэглэл тусгаар болсон цаг үетэй шууд тохирч байгааг генетикийн түвшинд тогтоолоо. Ингэхдээ зүйлийн генетик дифференциац нь Сэлэнгэ мөрөн ба Төв Азийн гадагш урсгалгүй ай сав тусгаарлагдах тэр түвшинд л буй болжээ. 
Генетикийн төрөлжилт бүтцийн генүүдийн нуклеотидын өөрчлөлтийн төдийгүй зохицуулагч генүүдийн өөрчлөлтөөр гарсныг илрүүллээ. Тэгэхдээ бүтцийн генүүдийн өөрчлөлт голлон газарзүйн тусгаарлагдмал байдлаар нөхцөлддөг бол зохицуулагч генүүдийн өөрчлөлт орчны нөхцлийн хүчтэй хэлбэлзлээр нилээд хэмжээгээр тодорхойлогддог нь Орог нуур, Түйн голын Алтайн османы (Oreoleucis. humilis, Or.potanini) популяциудад илүү тод илэрч байна. Зүүн гар /Джунгар/ын сугас (L.dzungaricus) загасны хувьд тусгаарлагдсан байдлыг шивэр сугастай (Leuciscus leuciscus baicalensis) харьцуулан морфологи ялгааны түвшинд авч үзвэл сул илэрч байгаa ба харин мтДНХ-ын локус болон зохицуулах генийн хувьд ч генетикийн илт ялгаа байгааг тогтоолоо. Энэхүу адил төстэй үр дүн Сэлэнгэ, Амар мөрний тусгаарлагдаагүй сав газрын түгээмэл зүйлүүдэд ажиглагдлаа. Сэлэнгийн сав газрын улаан нүдэн загасны хувьд сибирийн популяциудтай хэлбэрзүйн талаар нилээд төсөөтэй боловч хяналтын бүст мтДНХ-ийн үзүүлэлтээр Rutilus, Abramis төрлүүдээс ихэд давуу ялгаатай байна (Слынько, 2005).

Хэрлэн, Онон голын сав газрын варлан загасны гурван зүйлийн (Phoxinus perenurus, Ph.phoxinus, Ph.lagowski) популяцид бүтцийн ба зохицуулагч локусийн генетик ялгаа нилээд байна. Тэгэхдээ Лаговскийн варлан генетик үзүүлэлтээрээ бусад хоёр зүйлээс холдсон ба Сэлэнгийн сав газрын алтайн османтай (Oreoleuciscus humilis) ойролцоо байдал ажиглагдлаа. Энэ гарсан үр дүнгүүд геоуур амьсгалын хүчтэй болон харьцангуй түргэн өөрчлөлтүүд нь тэдгээр нөлөөлөлд өртсөн төрөл зүйлүүдийн популяцийг богино хугацаанд дасан зохицож хувьсан хөгжихөд хүргэснийг гэрчилж байна. Энэ хариу үйлдэл нь геномын бүтцийн хэсгийн хувьд ч, зохицуулалтын хэсгийн хувьд ч генетикийн судалгаагаар нилээд хүчтэй илэрч байна.
Төв Азийн гадагш урсгалгүй ай савын нууруудын экосистемийн өнөөгийн төрх нь галт уулын идэвхтэй ажиллагааг дагалдан Хангай-Саяны уулс бүрэлдэн тогтох үйл явц дууссаны дараа Үүсэн буй болжээ. Плиоцений сүүл үе хүртэл энэ газар нутгийн ихэнх хэсэгт оршиж байсан уудам их тэнгис далай жижигхэн нуурын бүлгүүдэд хуваагдан, тэдгээр жижиг нуурууд далайн бүх ай саваас тусгаарлагджээ. Эдгээр усан санд амьдарч байсан миоцены (дундад эриний) үеийн амьтны хийгээд ургамлын аймаг үндсэндээ бараг устан үгүй болжээ. Усан сангуудын амьдралын нөхөн сэргэлт плейстоцени хоёр дахь хагасаас эхэлжээ. Бид баруун Монголын орчин үеийн нууруудын экосистемийг яах аргагүй голоценийн үеийн гэж тодорхойлов.

Өнөө үеийн экосистемийн хэлбэржин тогтсон нь эх газрын эрс тэс уур амьсгал, галт уулын дараах усан сангуудын хүчтэй эрдэсжилтийн нөхцөлд үүсчээ. ЭнэхүҮ үйл явцын дүнд нэн түрүүнд Их Алтай, Говийн их уулархаг нутгийн мөсөрхөг ай савд хадгалагдан үлдсэн цөөн тооны зүйлүүд, мөн Саяны болон Хангайн уулсын саадыг даван туулах чадвартай евро-сибирийн төрөл зүйлүүдээс экосистем бүрэлдэн тогтжээ. ХX зууны сүүлчээс тус бүс нутгийн усан сангуудад Төв Азийн том уулсын техтоник хөдөлгөөнтэй зэрэгцэн бүс нутаг хуурайших явцыг бүрдүүлсэн дэлхийн гео-уур амьсгалын өөрчлөлт (дэлхийн дулааралт) хүчтэй нөлөө үзүүлэх болжээ. Мөн хүний үйлдлийн хүчин зүйлс ч нөлөөлж эхэлжээ.

Хоёр чухал ай сав буюу Баруун Монголын (Төв Азийн гадагш урсгалгүй ай сав), Сэлэнгэ мөрний ай савын экосистемийн тогтвортой байдлыг тодорхойлохын тулд эдгээр ай савын биологийн орчин үеийн олон янз байдал, усны хөвөгч ба ёроолын амьтад, загасны бүрэлдэхүүнийг тогтоов. Зоопланктоны бүлгэмдэл нь биологийн онцлог ба организмуудын амьдралын үечлэлээс шалтгаалан түргэн сэргэх, гадны хүчин зүйлүүдийн нөлөөллөөс түргэн 
өөрчлөгдөх зүй тогтолтой. Түүнээс гадна зоопланктон амьтад нь өндөр уулсын системийн хүчтэй бэрхшээлд тэр бүр үл өртөх евросибирийн эвритоп зүйлүүд тархан нутагшснаас нөхөн сэргээгдэж байдаг. Харин загасны бүлгэмдлийн тухайд эсрэгээрээ төвөгтэй, тухайлбал гадаад хүчин зүйлд удаан дасдаг тул бүлгэмдлийн нөхөн сэргэлт тухайн бүс нутагт миоценплиоцены үеийн амьтны аймгаас уулын тасархай усанд үлдэж хоцорсон цөөн тооны зүйлүүдээс үндсэндээ бүрдэж байна.

Алтайн нуурууд зоопланктоноор нилээд баялаг (62 зүйл), Говийн нуурууд хамгийн хомс (45 зүйл) бөгөөд харин Их нууруудын хотгорын ус нуурт 54 зүйл зоопланктон бүртгэгдлээ. Тэжээллэг чанарын коэффициентээр судалгаанд хамрагдсан бүх нуур эвтроф шинжтэй. Говийн нуурууд ба Их нуурын хотгорын усан сангууд гипертроф (хэт тэжээллэг үе рүүгээ) шилжих үедээ байгаa, харин Алтайн нууруудад энэХүҮ үзүүлэлтийн хэмжээ эвтроф чанарын хязгаарын дундаж түвшинд байна. Зоопланктон амьтдын тоон дээд үзүүлэлт Говийн нууруудад дундаж түвшинд, тэдгээрт хүрд хорхой зонхилж, биомассын хувьд саглагар сахалт хавч хэлбэртэнгүүд, Алтайн нууруудад хамгийн доод түвшинд, түүний биомассыг хавч хэлбэртэнгүүд тус тус бүрдүүлж байна. Монголын зарим нуурууд бүхэлдээ гипертроф орчинд шилжснээс төрөл зүйлийн олон янз буурсан, зоопланктоны тоон ба биомасст хүрд хорхойн эзлэх хувь нэмэгдэж эвтроф индикатор давамгайлсан нь Говийн ба Их нууруудын хотгорын ус нууруудад илүү харагдаж байна. Эвтроф үзэгдэл ихсэх эхний үе шатуудад сэлүүр хөлт, саглагар сахалт хавчхэлбэртны хувь хэмжээ нэмэгддэг, ингэснээр бүлгэмдлийн биомасс өсдөг (Алтайн нуурууд). Дунд үе шатанд нь саглагар сахалт хавчны эзлэх хувь нэмэгдэж, ингэснээр хүрд хорхойн хэмжээ өсөж биомасс буурах боловч хангалттай түвшинд хүрч хадгалагддаг (Их нууруудын хотгор). Эвтрофжих үзэгдэл нэмэгдэхийн хирээр бүлгэмдэлд хүрд хорхойн эзлэх хувь өсдөг. Үүний улмаас биомассын хэмжээ мэдэгдэхүйц багасдаг (Говийн нууруудын хөндий).

Сүүлийн арван жилд намагжих үйл явц түргэсэж байгаагийн нэг тод жишээг Орог нуурын байдал харуулж байна. 1998-2000-аад оны эхээр нуур ширгэх үйл явц эхэлсэн бөгөөд 2002 он гэхэд нуурын дийлэнх хэсэг хэвээр байсан. 2004 он гэхэд нуурын талбай, хэмжээ 3 гаруй дахин багасаж, нуурын усыг үндсэндээ цорын ганц цутгал болох олигтроф шинжтэй Түйн гол бүрдүүлж байлаа. Үүний улмаас сэлүүр хөлт хавчийн эзлэх хувь хэмжээ өсөж, биомасс нь нэмэгдэх байдал ажиглагдсан. 2010 он гэхэд голын адаг хэсэг байнга хатаж, нуурын хэмжээ тун их багассанаас (үндсэндээ бүрэн намагжих үйл явц ихсэж), сэлүүр хөлт хавчийн хэмжээ багасаж, салаа сахалт, хүрд хорхойн тоо хэмжээ нэмэгдсэн.

Өнөөгийн судалгааны дүнгээс үзвэл, загасны популяцид хуурайшлын мэдэгдэхүйц үйл явц, дэлхийн дулаарал нөлөөлсөн гэж батлах аргагүй юм. Гэсэн ч түүхэн цаг үед хуурайшлын улмаас Говийн нууруудын хөндий, Их нууруудын хотгорын усан сангуудын хоорондын усзүйн холбоо тасарсан байж ч магадгүй. Их нууруудын хотгор, Говийн нууруудын популяцийн бүлэглэлийн хооронд генетикийн төрөлжилт зарим талаар нэмэгдсэнийг нөхцөлдүүлсэн байж болох юм.

Загас агнуурын ач холбогдолтой зарим нууруудад загасны тоо хэмжээ, тэдгээрийн бөөгнөрөлийг эхолокацийн хэт авиагаар тодорхойлох тооллого анх удаа хийлээ. Баруун Монголын нууруудад загасны популяцийн тоо хэмжээ түүхэн үедээ өндөр байгаа ч, энэхүү нөөц нь агналтын хязгаар хэмжээ болон загасны нөөцийн шинжлэх ухааны үндэслэлийг алдагдуулбал амархан дуусах магадлалтай юм. Одоогоор зөвхөн Ховд голын ай савын Толбо нуураас л загас байнга олборлож байна. Гарсан үр дүнд тулгуурлан үзвээс загас агнуурын дарамт 30 жилийн хугацаанд Алтайн османы 
(Oreoleuciscus pewzowi) загасан идэшт хэлбэрийн биеийн урт хийгээд жингийн хувьд мэдэгдэхүйц өөрчлөлт үзэгдсэнгүй, харин ургамлан идэшт (Or.potanini) хэлбэрт нь энэХҮY Үзүүлэлтүүд илт мэдэгдэж байв. Иймд агнуурын нөлөөгөөр популяциудын нягтрал буурч нэн түрүүнд хамгийн элбэг байсан ургамал идэшт хэлбэртэн гадны нөлөөллийг эсэргүүцэх нөхөн үржих чадвар ийм сул байгаа нь Баруун Монголын хатуу ширүүн нөхцөлтэй ядмагхан экосистемд зүйлүүдийн бүрэлдэн тогтох, оршихуйн онцлогоос үүдэлтэй юм.

Монголын үндсэн гол мөрөн болох Сэлэнгэ, Орхоны загасны өнөөгийн тархац, биологийн онцлогийн талаарх судалгааны дүнд загасны бүлгэмдлийн зохицол, зүйлийн бүрдэл, ашиг шим, загасны бусад популяциийн биологийн төлөв байдалд хүний үйл ажиллагаанаас үүдсэн (татмын газрыг хагалах, томоохон хотуудын үйлдвэрийн ба ахуйн бохир ус, ашигт малтмалыг олборлох, боловсруулах, зохицуулалтгүй агналт) болон гео-цаг агаарын (тектоникийн улмаас өндөрших, дэлхийн дулаарал, хуурайшилт) хүчин зүйлүүдийн нөлөөллийг тогтоов. Сүүлийн 10 жилд голын ус эрдэсжих, бүлээсэх, эвтрофикацид орох, татмуудын усны түвшний горим эрс алдагдах, хатаж хуурайших зэргээс шалтгаалан загасны бүлгэмдэл өөрчлөгдөх үйл явц эрс нэмэгдэж байна. Хулдын төрлийн тул, зэвэг, хадран зэрэг үнэт зүйл загасны тоо эрс цөөрчээ. Тэдгээрийн нөхөн үржихүйн нөхцөл мэдэгдэхүйц алдагдаж, түрсээ шахах газар ховордов. Мөрөгийн төрлийн фитофиль цагаан зарам (Leuciscus leuciscus), улаан нүдэн, хэлтэг зэрэг загасны тоо өсөж, харь зүйл болох амарын цулбуурт, булуу цагаан, заадай загас (Abramis brama) шинээр нутагшсан байна. Физиологийн болон паразит өвчлөлийн хувь хэмжээ нэмэгдсэн нь ажиглагдлаа. Сэлэнгэ мөрөн, Орхон голын загасны бүлгэмдлийг бүхэлд нь, эсвэл зарим зүйл нэн ховор загасыг хамгаалах, хянах, нөхөн үржүүлэх цогц арга хэмжээ авч хэрэгжүүлэх шаардлагтай болжээ.

Амар мөрний ай савын усан сангуудаар мөргийн, хулдын төрлийн реофиль - оксифиль зүйл загас давамгайлж байна. Загас агнуурт бие гүйцсэн цөөн том загаснаас гадна дээрх зүйлийн жарамгай, жараахай ихээр баригдах болов. Зүйлийн бүрэлдхүүнээрээ хамгийн баялаг нь Барх, Онон голын дээд хэсэг Биндэр сумаас нилээд нам газар орших бөгөөд үндсэн голдрилдоо ч, дүүрэн устай хажуу хэсэгтээ ч хүчтэй түргэн урсгалтай, органик бус тундас элбэгтэй. Энд загасны аймгийн бүрэлдэхүүнээс, юуны өмнө эндхийн усны динамик, гидрохимийн нөхцөл таараагүй учраас Амар мөрний могор (Lethenteron reisneri), нуурын варлан, амар мөрний моголзой (Misgurnus mohoity). Амар мөрний антаахай ( Mesocottus haitej) загас байхгүй болсон байв.

Загасны аймгийн бүрэлдэхүүнээрээ хамгийн ядмаг нь Хэрлэн гол юм. Судалгааны хэсэг гүехэн устай, урсгал удаан, зах тойрон нь нарийхан, хатаж ширгэсэн, малын бэлчээрээр ашигласны улмаас амьтны нөлөөлөл ихтэй байв.. Хулдын овогоос зөвхөн Амарын хадран (Thymallus grubii), мөргийн овгоос 3 зүйл варлан (Лаговскийн, ердийн, нуурын), Амар мөрний моголзой. сахалт эрээлж (Orthrias [barbatulus] toni), шивэр чимхүүр яралж (Cobitis lebedevi) илэрсэн юм. Могор ба яралжийн төрлийн загас ер баригдсангүй.

Бархын голын дунд болон Онон голын Батширээт сумын нутаг дахь хэсэгт үндсэн голдрил ба дайвар цутгалуудад загасны аймгийн бүрэлдэхүүнийг харьцуулан үзэв. Бархын голын үндсэн голдрилд зэвэг, тул, амарын хадран, амарын цагаан (Coregonus chadary), амарын сугас (Leuciscus waleckii) зонхилж, бага устай хэсгүүд, урсгал сайтай хажуу салаанд ердийн варлан, сахалт эрээлж, чимхүүр яралж, амарын могор, зэвэг, тул, амарын сугасны жарамгай элбэг баригдсан. Усны дээд ургамалжилтай, хязгаарлагдмал (тогтонги) буюу аажуу 
урсгалтай татмын усанд Лаговскийн, нуурын болон ердийн варлан, гүрц (Gobio gobio albipinnatus), чимхлүүр яралж, хатгуурт халбаган (Acheilognatus asmussii) загас голлон баригдсан ба амар мөрний могор, сахалт эрээлж, амарын сугас болон зэвэг загасны жарамгай цөөн тоогоор тохиолдож байв.

Онон голын үндсэн голдрилд зэвэг, тул, амарын хадран (Thymallus grubii) тэдгээрийн жарамгай, цагаан хадар (Coregonus chadary), амар мөрний сугас, сахалт эрээлж, чимхлүүр яралж,ердийн варлан, Бархийн голын адагт Лаговскийн болон ердийн варлан, сахалт эрээлж, морин гурц, амарын хадран, Амар мөрний антаахай, тул, зэвэг загасны жарамгай, амар мөрний сугас, Дугуй амтнаас -Амар мөрний могор; татмын хязгаарлагдмал усан сангуудад дээрх зүйлүүдээс гадна 2 зүйл хатгуурт халбаган (Rhodeus sericeus, Acheilognatus asmussii) загас тохиолдож байлаа. Ийнхүу Монголын нутаг дэвсгэр дээрх Амар мөрний ай савын гол мөрний эхэн хэсгийн загасны аймгийн бүрэлдэхүүн, төрөл зүйлс нь усзүйн горим, мал амьтны ачааллаас нилээд хэмжээгээр хамаарчээ. Усны түвшний горим өөрчлөгдөх, мал амьтны дарамт ихсэх үед төрөл зүйлийн янз цөөрч байна. Ялангуяа өндөр исэлдсэн элементүүдийн улмаас Дугуй амтан / минога/, антаахай, Амар мөрний моголзой зэрэг ховор зүйл цөөрч байна. Эдгээр хүчин зүйл хоршсон нөхцөлд төрөл зүйлийн янз сүйрлийн хэмжээнд хүртэл цөөрөх байдал ажиглагдлаа. Чухалчлан хэлэхэд, тухайн орчинд нэн ховор төдийгүй, аж ахуйн үнэт зүйл тул, зэвэг, цагаан хадар, амарын сугас устаж үгүй болоход хүрч байна.

Сэлэнгийн сав нутагт хүн ам олноор суурьшиж, ашигт малтмалыг олборлох, боловсруулах ажиллагаа жилээс жилд өргөжиж байгаагийн улмаас гол мөрөн бохирдох үйл явц нэмэгдсээр байна. Өдгөө зөвхөн Сэлэнгийн сав нутагт 140 гаруй алт олборлох аж ахуй бүртгэгджээ. Технологийн үйл ажиллагаа зөрчсөн, голын голдрилыг өөрчилсөн зэргээс үҮдэн ус бохирдон усны агууламжин дахь хорт бодисын хэмжээ (байж болох хэмжээнээс 3-5 дахин их) өсөж байна. Сэлэнгийн, ялангуяа Амар мөрний ай савд татмын мод огтлох, ойн түймэр зэргийн улмаас голуудын усан сан сөрөг нөлөөлөлд өртөж байна. Онон голын эх, дунд хэсэг нилээд хэмжээгээр сүйджээ. Хэрлэн, Халх голын тэгш хөндийд тариалан услах зорилгоор усны хаалт барих нь нэмэгдсэн байна. Энэ бүх хүчин зүйлийн уршгаар голуудын биогений урсац, усны эрдэсжилтэнд байгалийн гидрохимийн саад бэрхшээл учирч байна. Түүнээс гадна цаг уурын өөрчлөлт, хүний өсөн нэмэгдэж буй нөлөө нь харь зүйлийн халдвар өсөхөд хүргэв.

Загасны уугуул нутагшлын хувьд экологийн хэлбэрийн харьцаанд өөрчлөлт гарч, эмгэгийн тоо өсөн, нутгийн төрөл зүйл цөөрч, зарим зүйл загасны өсөлтийн хурдац, үржлийн хэв шинж өөрчлөгджээ. Тухайлбал, Төв Азийн гадагш урсгалгүй ай савын загасны өсөлт, хооллолт, тархалтанд усны хэмжээ, түвшний бууралт, агнууртай холбоотойгоор нягтралын зохицол онцгой нөлөө үзүүлж байна.Үүсэн бий болсон эдгээр нөхцөлд аж ахуйн үнэт зүйл загас тул, зэвэг, шивэр болон амар мөрний хадран, амарын булуу цагаан (Cyprinus carpio haematopterus), мөнгөлөг хэлтэг (Carassius auratus gibelio), амарын цулбуурт (Parasilurus asotus), амарын ба ердийн цурхай (Esox reichertii, E.lucius) болон монгол орны унаган зүйл (алтайн гурван зүйл осман - Oreoleuciscus pewzowi, Or.potanini, Or.humilis), Монгол ба дээд Енисей мөрний (Thymallus brevirostris, Th. svetovidovi), хөвсгөлийн хадран (Th. nigrencens) зэрэг зүйл загаснуудад ихээхэн анхаарах шаардлага гарч байна.

Ай савын харьяалал, усзүйн байдлаас үл хамаарах экологийн нийтлэг зарим зүй тогтол илэрлээ. Эрдэсжилт ба эвтрофикацийн ихсэлтийн тогтвортой хандлага ажиглагдсан ба үүнийг 1970-80аад онуудын адил төстэй үзүүлэлтүүдтэй 
харьцуулахад илүү тод харагдаж байна. Усны зоопланктон /хөвөгч амьтан/, загасны бүлгэмдлийн бүтцэд мэдэгдэхүйц өөрчлөлт илрэв. Зоопланктоны бичил жижиг биет салаа сахалт хавч болон хүрд хорхойн зүйлүүдийн эзлэх хувь мэдэгдэхүйц өслөө. Загасны аймгийн хувьд жижиг хэмжээний лимнофиль зүйүүд олширч, харин аж ахуйн үнэтэй тул, зэвэг, хадран зэрэг реофил оксифил загасны эзлэх хувь хэмжээ нилээд буурчээ. Ажиглагдаж буй ихэнХ энэхүү сөрөг үзэгдэл нь дэлхийн дулаарал, хуурайшил, циклоны идэвхжил зэрэг дэлхийн геоцаг уурын хүчин зүйлүүдийн нөлөөллөөс үүдсэн байна. Эдгээр хүчин зүйл нь усны түвшин буурах, усан сангуудад эрдэс, биогенүүдийн хэмжээг нэмэгдүүлэхэд шууд нөлөөлжээ. Үүний уршиг Төв Азийн гадагш урсгалгүй болон Сэлэнгэ мөрний ай сав, ялангуяа Орхон, Туул голын савд хамгийн тод илэрч байна. Антропогены хүчин зүйлүүдийг задлан шинжилж үзвээс усны бүх ай савд мал аж ахуйн нөлөө харьцангуй адил байна. Одоохондоо үйлдвэрлэлийн болон аж ахуйн бохирдуулалтын тийм мэдэгдэхүйц нөлөө хараахан тодроогүй байна. Эдгээр хүчин зүйлүүдийн орон нутгийн чанартай нөлөөлөл Эрдэнэт хотын

Үүсгэж, улмаар Сэлэнгэ, Орхон, Туул, Шишгэд, Онон голын сав нутагт тул, зэвэг, хадран, цурхай, булуу цагаан загасны тоо эрс буурах шалтгаан болж байна.

Дүгнэлт

Монгол-Оросын хамтарсан биологийн иж бүрэн экспедицийн гидробиологийн судалгааны гол үр дүнг дараах байдлаар товч тодорхойлж байна.

Сүүлийн 10 жилд намагжих, голуудын ус бүлээсэх, эрдэсжилт нэмэгдэх мөн татмын усан сангийн усны түвшний горим алдагдсан, хуурайшсан зэргээс шалтгаалан Монгол орны бүх ус нуурын амьтан, ургамал, загасны бүлгэмдэл өөрчлөгдөх үйл явц идэвхжсэн байна. Сэлэнгийн ба Төв Азийн гадагш урсгалгүй ай савын зэс молибдений уулын баяжуулах үйлдвэр, томоохон хотуудын (Улаанбаатар, Дархан) ба үйлдвэрийн аргаар алт олборлож буй бүс нутагт (Туул голын доод хэсэг, Орхон голын цутгалангууд) илт мэдрэгдэж байгаa юм. Сэлэнгэ мөрний дунд хэсэг, Эгийн голын сав нутагт татмын газрыг хагалах ажиллагаа идэвхжсэний улмаас элдэв эрдэс ба органик бодис урсан орох явдал өсчээ. Онон голын ай савд татмын ойг нилээдгүй огтлосноос төсөөтэй байдал ажиглагдаж буй. Хамгийн сүүлийн үеийн ноцтой асуудлын нэг нь усан цахилгаан байгууламж барих, ус ашиглалт болоод байна.

Хэрлэн голын дунд, доод урсгалд услалтын зорилгоор усны хаалт барих нь ихэссэний уршгаар татмын газрууд намагжих, давсжих үйл явцыг түргэтгэж байгаа юм. Завхан голын сав нутагт, ЧоноХарайхын гол дээр усан цахилгаан станцууд барьсан нь Их нууруудын хотгорын бараг бүх үндсэн ус нуурын /Айраг, Хйргас/ усны түвшин үлэмж хэмжээгээр буурах аюул дагуулж, энэ нь усны амьтдын бүлгэмдлийн бүтцэд нөлөөлж загасны үржлийн газар хумигдав. Түүнчлэн сүүлийн жилүүдэд спорт сонирхогчийн нэрийдлээр хулгайгаар загас агнах нь бас нэгэн сөрөг нөлөөлөл

усны экосистемийн экологийн төрх байдлыг нарийвчлан тодорхойлов. Өдгөө Монголын Дугуй амтан /миног/-ийн ба загасны аймаг нь 2 багийн 14 язгуурын 75 зүйлээс бүрдэж байна. Төв Азийн гадагш урсгалгүй ай савын усан системүүд бүрэлдэн тогтох, гидробионтуудын хувьсал хөгжилд кайнозойн гео-цаг уурын хүчтэй дөрвөн үйл явц (плиоцены сүүлч үеийн мөстлөг, плиоцены ба плейстоны зааг дахь Саян-Хангайн орогенезийн идэвхжлийн Ye, голоцены бага мөстлөгийн үе, эцэст нь дэлхийн дулаарлын одоогийн $\mathrm{Ye}$ ) шийдвэрлэх ач холбогдолтой байжээ. Тус ай савын үндсэн гол мөрний орчин үеийн амьгүй байгалийн /абиотик/ шинжүүд 
гэвэл, усны түвшингийн нилээд хэлбэлзэл (10 м хүртэл), үндсэн гол мөрний усны эрдэсжилтийн хувьсалт, өөрөөр хэлбэл бага эрдэсжилтээс өндөр эрдэсжилт, халуун хүйтний /температурын/ хоног, улирал болон жилийн өөрчлөлт тухай бүр өндөр байна. Ховд, Завхан, Тэс голын ай сав нь биотын төрөл зүйлээр ядмаг харин эндемизмийн хувьд өндөр байна.

Төв Азийн гадагш урсгалгүй ай савын загасны зүйлүүд филогенетикийн хувьд залуу бөгөөд амьгүй хүчин зүйлийн ихээхэн хэлбэлзэлтэй, хатуу ширүүн нөхцөлд амьдрах чадвар бүхий биологийн өвөрмөц шинжтэй болжээ. Тус бүс нутгийн загасны аймаг нь плиоцен, плейстоны сүйрэл дагуулсан гео-цаг уурын үзэгдлүүдийн дараа үлдэж хоцорсон евросибирийн ба хятадын загасны аймгийн цөөн тооны элементүүдийн суурин дээр плейстоны дунд үеэс өдгөө хүртэлх түүхэн богино хугацаанд амьтны хэлбэрүүд хэрхэн бүрэлдэн тогтох процесс явагдсаныг судлан тайлбарлав. Ховд, Завхан голын эх нь эдгээр элементүүд хадгалагдан үлдэх нутаг нь байжээ.

Монгол орны усан сангуудын амьтан, ургамлын ангилал зүйн ба амьтны аймгийн тодотгол хийв. Монголын унаган загасны нэг алтайн осман - /Oreoleuciscus pewzowi.
Or.potanini. Or.humilis/, хадран - /Thymallus $s p . /$ загасны популяцийн генетик ялгарал, ангилал зүйг анх удаа молекул генетикийн судалгаагаар тодруулав. Төв Азийн гадагш урсгалгүй ай савын усан сангуудын хосгүй чухаг нь загасны эндемизмийн өндөр үзүүлэлтээр тодорхойлогдож байна. Баруун Монголын нуруудын зооплактоны сээр нууруугүйтэн 94 зүйл, түүний дотор 46 зүйл хүрд хорхой, 36 зүйл салаа сахалт, 12 зүйл сэлүүр хөлт хавч байна.

Төв Азийн гадагш урсгалгүй ай савын загасны өсөлт, хооллолт, тархалтанд усны татрал багасалт, агнуур ашиглалттай холбоотойгоор нягтралын зохицуулалт нэн нөлөөтэй байгаа нь хамгаалах байгуулгуудын эрчимтэй ажиллагаа шаардагдаж байна. Хүний нөлөөллийн шинэ том хүчин зүйл бий болсон, тухайлбал Завхан голын эх, Ховд голын доод хэсэг усан техникийн зохицуулалтанд өртсөнөөс эдгээр голын усны тэнцвэр, загасны популяциудын тоо хэмжээ, бүхэлдээ экосистемийн үйлчлэл, хүн амын амьдрал үйл ажиллагаанд ноцтой тусч байгаа нь харагдлаа. Төв Азийн гадагш урсгалгүй ай савын гол мөрний гандуу бүст эхлэн байгуулсан усан сангуудын экосистемийн мониторингийн эрчимтэй судалгаa шаардагдаж байна.

\section{Аиигласан бүтээлийн жсагсаалт}

1. Баасанжав Г., Дгебуадзе Ю.Ю., Дёмин А.Н., Дулмаа А. и др. Обзор видов ихтиофауны МНР. Глава 3. // Рыбы МНР.М. Наука.1983. с. 102-224.

2. Баасанжав Г., Дгебуадзе Ю.Ю., Дёмин А.Н., Дулмаа А. и др. Экология и хозяйственное значение рыб МНР. .М. Наука.1985. с. 9-174.

3. Дгебуадзе Ю:Ю. Механизмы формообразования и систематика рыб рода Oreoleuciscus (Cyprinidae, Pisces) //Зоологические исследования в МНР. М.Наука.1982. с.81-92.

4. Дгебуадзе Ю.Ю.,Дулмаа А. Периодические климатические изменения и динамика популяций рыб водоемов и водотоков Долины озер. В кн.: Экология и природопользование в Монголии. Сборник научных трудов. 1992. Пущино.с.192-201.

5. Дгебуадзе Ю.Ю.,Дулмаа А., Мунхбаяр Х. О находке представителя рода Oreoleuciscus (Cyprinidae) в бассейне р.Селенги // Вопр. Ихтиологии,2003. Т.43. №3. c.420-422.

6. Дулмаа А. Биология озер МНР.Автореф.дис. докт.биол.наук. Иркутск. 1974. 54.c.

7. Маринов Н.Д. Древнее оледенение Монголии. Изв.АН СССР.серия геогр.1954. №6. с. 2840.

8. Слынько Ю.В.Дгебуадзе Ю.Ю. Новые данные по рыбам рода (Oreoleuciscus). 
Популяционно-генетический анализ. Экосистемы Монголии и пограничнных территорий соседних стран: природные ресурсы,биоразнообразие и экологические перспективы: Труды Междунароной конференции. Улаанбаатор /Монголия/. 2005, Изд-во Бемби Сан. C.319-323,

9. Сычевская Е.К. История пресноводной ихтиофауны кайнозоя Северной Евразии. Автореф. дис. докт.биол.наук. М. 1991. 48 c.

10. Dulmaa A.,Munkhbayar Kh.Nakagawa M. New recorded of Oreoleuciscus humilis (Cyprinidae) in the Orkhon River Basin: Book of Abs.Int.Confer."Biodiversity of Euro-Asia continental wetlands"., Mongolia, Ulaanbaatar.2004. p.8-9. 


\title{
Summary
}

\section{Molecular-phylogenetic analysis on some fishes of Mongolia}

\author{
A.Dulmaa \\ Research Center for Fishbreeding \\ E-mail:adulmaa@yahoo.com
}

The Joint Mongolian-Russian Complex Biological Expedition is the biggest biological expedition in iterms of Water ecosystems of Mongolia. Over 40 years, large - scale integrated research has been analysis of natural and antropogenic processes and basic principles of rational exploitation. The aim is to fulfill complex hydrobiological, ichthyological and hydrological estimation of water resources state and propose measures for their protection

Interrelation of global and local geo-climatic changes in territory of Mongolia in Cenozoic Era with evolution of endemic fishes of genera Oreoleuciscus is analysed. It is shown, that all basic stages of geo-climatic transformation directly defined occurrence, formation of species, morpho-ecological specialization and formation of geographic areas of species and their population organization.Evolutionary and population characteristics of the Altai osmans are given on the basis of genetically analysis of locuses mtDNA and the nuclear locuses coding isoenzymes.

According to recent findings and investigations fauna of Lampreys and fishes of Mongolia consist of about 75 species of 14 families and 2 orders. 11 new species of fish, including one new invader bream (Abramis brama) were noted in the country waters last 15 years. According to new results two species of the Altai osmans (Oreoleuciscus angusticephalus, O.dsapchynensis) and one species of graylings (Thymallus arcticus) are excluded from the list of fish fauna of Mongolia. Recently Almai osmans were found not only in the waters of the Central-Asian closed basin, but also in rivers and small lakes of the Selenga River basin (Dgebuadze, Dulmaa, Munkhbayar 2003; Dulmaa A.,Munkhbayar Kh.Nakagawa M.,2004).

Esseantial climate change and increasing of human impact transformed Mongolian fish population during last 40 years. As a result bias on ratio of ecological guilds, pathology number increasing, local diversity declining, and changes in species distribution, rate of growth and fecundity of many species of fish are observed. One of the main factors, influencing on fish populations, is gold mining in the rivers Arctic Ocean basin. In new conditions more attention demand both commercially important species as taimen, lenok, Baikal and Amur graylings, Amur carp, goldfish, Amur catfish, Amur and northern pikes, minnows, burbot, dace, and endangered and endemic species as Altai osman, Mongolian upper Enisey and Kosogol graylings, stone loaches and sculpin.

Anthropogenic load on the water bodies of the Central-Asian closed basin is connected, first of all, with the constraction of hydraulic structures (dams in the basin of the Kobdo and Dzavkhan rivers), increase of pullution, and intensification of fishery. Evaluation of modern condition of water ecosystems and fish population parateters of this basin remains the main purpose of research for the years immediately ahead. 